\title{
The Incidence of Sick Building Syndrome and Its Causes on Employees at the Governor's Office of West Sulawesi Province
}

\section{Kejadian Sick Building Syndrome dan Faktor Penyebabnya pada Karyawan Di Kantor Gubernur Provinsi Sulawesi Barat}

\author{
Ridhayani Adiningsih, Miftah Chairani Hairuddin \\ Department of Environmental Health, Polytechnic of Health Mamuju \\ Jl. Poros Mamuju - Kalukku Km. 16, Tadui, Mamuju Regency, West Sulawesi 60172 Indonesia
}

\begin{abstract}
Introduction: Indoor air quality greatly affects human health because almost $90 \%$ of human life is indoors. Some symptoms that are often felt by employees in a building with Sick Building Syndrome (SBS) are fatigue; headaches; symptoms of eye, nose and throat irritation; skin irritation; dry cough, increased irritability and difficulty in concentration; nausea; drowsiness; and hypersensitivity to odor. This research aims to determine the relationship of air quality in space to the incidence of Sick Building Syndrome. Methods: This research was an analytic survey research with cross sectional approach. The samples in this study were employees who were in the Building D of the Provincial Governor's Office, West Sulawesi totalling 82 people. This research was carried out by measuring indoor air quality and giving questionnaires to find out the SBS events. Results: The results of room temperature measurements ranged from $26.14-41.46^{\circ} \mathrm{C}$, humidity measurement was $\geq 60 \%$, light intensity was $\leq 100$ lux, the chemical quality of CO in the air was $\leq 29 \mathrm{mg} / \mathrm{m}^{3}, \mathrm{CO}_{2}$ levelin the air was $\leq 1000 \mathrm{ppm}$, and dust level was $\geq 0.15 \mathrm{mg} / \mathrm{m}^{3}$. Besides, there was a significant relationship between air temperature and dust levels on the incidence of Sick Building Syndrome (SBS), with p value of 0.006. Conclusion: It can be concluded that factors that influenced the occurrence of SBS were air temperature and dust concentration in the room.
\end{abstract}

Keywords: indoor air quality, office, sick building syndrome

\begin{abstract}
ABSTRAK
Pendahuluan: Kualitas udara dalam ruang sangat mempengaruhi kesehatan manusia, karena hampir $90 \%$ hidup manusia berada dalam ruangan.Beberapa gejala yang sering dirasakan pada 20-30\% karyawan dalam suatu gedung dengan adanya Sick Building Syndrome (SBS) adalah kelelahan, sakit kepala, adanya gejala iritasi mata, hidung, dan iritasi tenggorokan, iritasi kulit, batuk kering, iritabilitas meningkat dan sukar konsentrasi, perasaan mual, mengantuk, dan adanya hipersensitivitas terhadap bau. Tujuan penelitian ini adalah untuk mengetahui hubungan kualitas udara dalam ruang terhadap kejadian Sick Building Syndrome. Metode: Penelitian ini penelitian survey analitik dengan pendekatan cross sectional. Sampel dalam penelitian adalah pegawai yang berada di Gedung D Kantor Gubernur Prov. Sulawesi Barat sejumlah 82 orang. Penelitian ini dilaksanakan dengan melakukan pengukuran kualitas udara dalam ruang dan pemberian kuesioner untuk mengetahui kejadian SBS. Jumlah kejadian SBS sebanyak 42 responden. Hasil: Hasil dari pengukuran suhu udara yaitu berada pada rentang $26,14-41,46^{\circ} \mathrm{C}$, pengukuran kelembaban sebesar $\geq 60 \%$, pengukuran intesitas cahaya sebesar $\leq 100$ lux, kualitas CO di udara sebesar $\leq 29 \mathrm{mg} / \mathrm{m}^{3}$, level $\mathrm{CO}_{2}$ di udara sebesar $\leq 1000 \mathrm{ppm}$, dan level debu sebesar $0.15 \mathrm{mg} / \mathrm{m}^{3}$. Di samping itu, terdapat hubungan antara suhu udara dan level debu dengan kejadian Sick Building Syndrome, dengan nilai p 0,006. Simpulan: Dapat disimpulkan bahwa faktor yang mempengaruhi kejadian SBS adalah suhu udara dan konsentrasi debu dalam ruangan.
\end{abstract}

Kata kunci: kualitas udara ruangan, sick building syndrome, suhu udara

Corresponding Author:

Ridhayani Adiningsih

Email: Ridhayaniadiningsih@gmail.com

Telephone: +6285255750995

\section{INTRODUCTION}

Indoor air quality greatly affects human health because nearly $90 \%$ of human life is indoors. As many as 400 to 500 million people, especially in developing countries, are dealing with the problem of indoor air pollution. According to 
the National Institute of Occupational Safety and Health (NIOSH), indoor air quality problems are generally caused by a number of factors, namely lack of air ventilation (52\%), the presence of indoor contaminants $(16 \%)$, outdoor contaminants $(10 \%)$, microbes $(5 \%)$, building materials $(4 \%)$, and others (13\%) (Wulandari, 2013).

Sick building syndrome (SBS) is a nonspecific group of symptoms that are triggered by a length of stay in a building and caused by poor indoor air quality. These symptoms are only felt during activities in the building, and they disappear naturally when the the person is being on holidays or leaving the building (Mukono, 2014).

SBS is characterized by fatigue, heavy/lethargic feeling, headache, nausea, difficulty in concentration, itching, burning, irritation, hoarseness, dry throat, cough, dry or flushed skin, itching on the scalp or ears, or dry nutritional status. Work environment is the condition or circumstances around employees that can affect employee performance, such as the presence of air conditioning, lighting, temperature, humidity, dust, and so on (Ikmala, Ma'rufi and Munawir, 2018).

Moreover, there is a relationship between demographic factors, which are age factors ( $p$-value 0.014 ), work related factors, and ventilation system (air flow velocity) (p-value 0.036), with sick building syndrome symptoms in workers (Saffanah and Pulungan, 2017). A study conducted by Asri (2019) showed that there was a relationship between lighting $(p=0.001)$, age $(p=0.006)$, psychosocial conditions $(0,025)$, smoking habits $(p=0,025)$, and history of disease $(\mathrm{p}=0,038)$ with symptoms of SBS.

West Sulawesi Province has office areas consisting of several Provincial Work Units, where most of the work is done indoors. The high activity in the room raises the risk of the occurrence of SBS. Each building is equipped with air conditioning, so the employees are only contaminated with indoor air without any exchange of air from outside. Measuring air quality and symptoms of SBS incidents on employees are deemed necessary so that the results of air quality measurements and SBS incidents will be obtained. For this reason, the authors are interested in conducting study on indoor air quality on the incidence of Sick Building Syndrome (SBS) in office areas in West Sulawesi.

\section{METHODS}

This study was an analytical survey study with cross sectional observational approach. The variables in this study were the occurrence of SBS in relation to air temperature, humidity, light intensity, levels of $\mathrm{CO}$ and $\mathrm{CO} 2$, levels of dust, and the number of germs in the air. The research was conducted in July 2019. This research was carried out after obtaining a recommendation for ethical approval No: 130 / KEPK-PTKMKS / II / 2019.

Sick building syndrome is a set of symptoms experienced by respondents or employees in a building that are related to the length of time they have been in the building, but there is no disease or specific cause that can be identified. A person is declared to have SBS if they have complaints of at least 2 or more of the symptoms at the same time while in the room, and the symptoms slowly disappear when he/she is leaving the room or building.

Measurements of air temperature, humidity and light intensity variables were done using an Environment-meter. Measurements of variable levels of $\mathrm{CO}$ and $\mathrm{CO} 2$ were done using the Air Quality Monitor. Measurement of dust levels was done using a Low Volume Air Sampler (LVAS). Measurement of the number of germs in the air was done using a Microbiology Air Sampler.

The population of the research was employees who were in Building D, West Sulawesi Governor's office. The sample in this study was 82 employees of the West Sulawesi Governor's office. Data analysis techniques were carried out using univariate analysis to analyze each variable and bivariate analysis to see the relationship between the incidence of SBS and other research variables.

\section{RESULTS}

\section{Characteristics of Respondents}

Based on Table 1, it is known that the majority of respondents in this study were in the age group of $<40$ years with 58 people $(70.7 \%)$ and the minority was in the age group of $\geq 40$ years with 24 people $(29.3 \%)$ and it is known that the gender of the respondents was dominated by males of 49 people (59.8\%), followed by females of 33 people $(40.2 \%)$. Based on Table 2, it is known that the majority of respondents involved in this studywere respondents with a length of work $\geq 5$ years with 68 people $(82.9 \%)$.

The results of the study in Building D West Sulawesi Provincial Office in 2019 from 82 respondents show that the number of respondents who experienced SBS complaints were 42 respondents $(51.3 \%)$ while respondents who did 
not experience complaints were 40 respondents (48.7\%). In other words, the results show that more respondents experienced complaints about SBS, so this needs to be paid attention to.

Based on the results of the study, it is shown that in relation to the symptoms of SBS, most respondents complained about drowsiness of 36 respondents $(43.9 \%)$, followed by flu symptoms of 31 respondents $(37.8 \%)$, headache of 24 respondents $(29.3 \%)$, flatulence of 23 respondents $(28.4 \%)$, dry skin of 22 respondents $(26.8 \%)$, eye irritation of 22 respondents $(26.8 \%)$, dizziness of 22 respondents (26.8\%), hand and arm pain of 20 respondents $(24,4 \%)$, back pain of 19 respondents (23.2\%), runny nose of 17 respondents $(20.7 \%)$, poor concentration of 14 respondents (17.1\%), chest tightness 10 respondents $(12.2 \%)$, chronic fatigue of 8 respondents $(9.8 \%)$, chest pain of 7 respondents $(8.5 \%)$, nausea of 6 respondents $(7.3 \%)$, stress 5 respondents $(6.1 \%)$, and skin rash of 4 respondents $(4.9 \%)$.

Table 1. Distribution of Respondents Based on Employees' Age and Gender in Building D, West Sulawesi Provincial Office in 2019

\begin{tabular}{ccc}
\hline Age & Frequency & Percentage (\%) \\
\hline$<40$ & 58 & 70.7 \\
$\geq 40$ & 24 & 29.3 \\
\hline Total & 82 & 100 \\
\hline Gender & & \\
Male & 49 & 59.8 \\
Female & 33 & 40.2 \\
\hline Total & 82 & 100 \\
\hline
\end{tabular}

Table 2. Distribution of Respondents based on Employees' Length of Work in Building D, West Sulawesi Provincial Office in 2019

\begin{tabular}{ccc}
\hline Length of Work & Frequency & Percentage $\mathbf{( \% )}$ \\
\hline$<5$ years & 14 & 17.1 \\
$\geq 5$ years & 68 & 82.9 \\
\hline Total & 82 & 100 \\
\hline
\end{tabular}

Table 3. Distribution of Respondents Based on SBS Incidence in Building D, West Sulawesi Provincial Office in 2019

\begin{tabular}{ccc}
\hline SBS Incidence & Frequency & Percentage (\%) \\
\hline Experienced SBS & 42 & 51.3 \\
Not experienced SBS & 40 & 48.7 \\
\hline Total & 82 & 100 \\
\hline
\end{tabular}

\section{Physical Quality of Indoor Air}

The results of the measurement of the physical quality of air in Building D of the Governor's Office show that that the temperatures ranged from $26.14^{\circ} \mathrm{C}-41.56^{\circ} \mathrm{C}$. Moreover, the range of humidity in the room was $66.36 \%-79.3 \%$, which means that the humidity was in an abnormal number $\geq 60 \%$. Moreover, the results show that the range of light intensity was $10.44-87.98$ lux, which means that the light intensity was at an abnormal number of $<100$ lux.

\section{Indoor Air Chemical Quality}

The measurement results of air chemical parameters show that indoor $\mathrm{CO}$ levels were within normal limits with a value of $0.66-3 \mathrm{mg} / \mathrm{m}^{3}$. The measurement of $\mathrm{CO}_{2}$ levels also show that the results were within normal limits with a value of 348.4 - $612.4 \mathrm{ppm}$. Meanwhile, for the measurement of varying dust levels, some were in normal and abnormal limitsin the range of $0.02-6.46$ Thus, further measurement was conducted in statistical testing, and the result obtained a $\mathrm{p}$ value $<0.05$,

Table 4. Distribution of Respondents Based on SBS Symptoms in Building D, West Sulawesi Provincial Office in 2019

\begin{tabular}{|c|c|c|c|c|}
\hline \multirow{2}{*}{ SBS Symptom } & \multicolumn{2}{|c|}{ Yes } & \multicolumn{2}{|c|}{ No } \\
\hline & $\mathbf{n}$ & $\%$ & n & $\%$ \\
\hline Hoarse/Dry Voice & 21 & 25.6 & 61 & 74.4 \\
\hline Dry Skin & 22 & 26.8 & 60 & 73.2 \\
\hline Skin Rash & 4 & 4.9 & 78 & 95.1 \\
\hline Eye irritation & 22 & 26.8 & 60 & 73.2 \\
\hline Runny Nose & 17 & 20.7 & 65 & 79.3 \\
\hline Out of Breath & 7 & 8.5 & 75 & 91.5 \\
\hline Chest tightness & 10 & 12.2 & 72 & 87.8 \\
\hline Flu Symptom & 31 & 37.8 & 51 & 62.2 \\
\hline Dizziness & 22 & 26.8 & 60 & 73.2 \\
\hline Headache & 24 & 29.3 & 58 & 70.7 \\
\hline Drowsiness & 36 & 43.9 & 46 & 56.1 \\
\hline Chronic Fatigue & 8 & 9.8 & 74 & 90.2 \\
\hline Chest Pain & 7 & 8.5 & 75 & 91.5 \\
\hline Back Pain & 19 & 23.2 & 63 & 76.8 \\
\hline $\begin{array}{l}\text { Hand and Arm } \\
\text { Pain }\end{array}$ & 20 & 24.4 & 62 & 75.6 \\
\hline $\begin{array}{lccr}\mathrm{P} & \mathrm{o} & \mathrm{o} & \mathrm{r} \\
\text { Concentration } & \end{array}$ & 14 & 17.1 & 68 & 82.9 \\
\hline Stress & 5 & 6.1 & 77 & 93.9 \\
\hline Nausea & 6 & 7.3 & 76 & 92.7 \\
\hline Flatulence & 23 & 28.4 & 58 & 71.6 \\
\hline
\end{tabular}


which indicates that there was a relationship between dust levels and the incidence of SBS. The results of measurements of indoor dust levels show that most of the dust levels were above normal $>0.15 \mathrm{mg} / \mathrm{m}^{3}$.

\section{Microbiological Quality of Indoor Air}

The results of measuring the number of germs in the air show that the average total of air microbiology in the building is still within the allowed threshold value. Some points have a fairly high germ count but have not exceeded the standard, specifically in the General Bureau room with 267

Table 5. Air Physical Quality Measurement Results in Building D, West Sulawesi Provincial Office in 2019

\begin{tabular}{ccccc}
\hline & & \multicolumn{3}{c}{ Result } \\
\cline { 3 - 5 } & Morning & 27.42 & 70.36 & 34.26 \\
General & Noon & 30.88 & 68.42 & 15.02 \\
Bureau & Afternoon & 30.7 & 68.64 & 10.43 \\
Public & Morning & 30.38 & 66.36 & 87.98 \\
Order & Noon & 31.66 & 64.96 & 35.02 \\
Enforcer & Afternoon & 41.56 & 72.4 & 69.14 \\
People & Morning & 26.52 & 69.08 & 10.44 \\
Welfare & Noon & 26.14 & 79.3 & 20.85 \\
Department & Afternoon & 27.6 & 75.28 & 22.46 \\
\hline
\end{tabular}

Table 6. Air Chemical Quality Measurement Results in Building D, West Sulawesi Provincial Office in 2019

\begin{tabular}{ccccc}
\hline & & \multicolumn{3}{c}{ Result } \\
\cline { 3 - 5 } & Morning & 0.66 & 514.4 & 0.02 \\
General & Noon & 3 & 441 & 0.79 \\
Bureau & Afternoon & 0.92 & 543.8 & 1.53 \\
Public & Morning & 0.48 & 352.6 & 0.97 \\
Order & Noon & 0.93 & 348.4 & 6.46 \\
Enforcer & Afternoon & 1.05 & 369 & 4.46 \\
People & Morning & 1.30 & 612.4 & 2.16 \\
Welfare & Noon & 0.64 & 494 & 2.03 \\
Department & Afternoon & 0.98 & 584.2 & 1.55 \\
\hline
\end{tabular}

Table 7. Results of Measurement of Air Microbiology Quality in Building D, West Sulawesi Provincial Office in 2019

\begin{tabular}{cccc}
\hline & Morning & 49 & Normal \\
General & Noon & 267 & Normal \\
Bureau & Afternoon & 196 & Normal \\
& Morning & 47 & Normal \\
Public Order & Noon & 20 & Normal \\
Enforcer & Afternoon & 40 & Normal \\
People & Morning & 359 & Normal \\
Welfare & Noon & 88 & Normal \\
Department & Afternoon & 105 & Normal \\
\hline
\end{tabular}

colonies $/ \mathrm{m}^{3}$ during the day, 196 colonies $/ \mathrm{m}^{3}$ in the afternoon, and in the People Welfare Department with 359 colonies $/ \mathrm{m}^{3}$ in the morning and 105 colonies $/ \mathrm{m} 3$ in the afternoon. It is suspected that the microbiological pollution in the building is obtained from the activities of employees entering and leaving the office. The microbiology is carried by the air that enters and exists through the vents, which will then stick to the dust and cloth in the building.

\section{DISCUSSION}

\section{Sick Building Syndrome Incidence}

Based on Table 3, it is shown that the number of respondents who experienced SBS complaints was higher than those who did not have complaints. Based on interviews conducted with respondents, it is known that complaints would disappear after the respondents left the room. This is in line with the research from the Environmental Protection Agency (EPA), suggesting that complaints are only felt when people are doing activities in the building and disappear during work holidays (Verayani, 2018).

The incidence of SBS can be caused by several factors, including age. The age of an employee has an influence on the level of risk for a disease related to work. In this study, the respondents' ages were categorized into two categories, whichwere $<40$ years and $\geq 40$ years. The results of the chi square statistical test showed a value of $\geq 0.05$, which means there was no relationship between age and the incidence of SBS. The results of this study are inconsistent with research conducted by 
Saffanah and Pulungan which showed that there was a relationship between age factor (p-value 0.014) with sick building syndrome symptoms workers (Saffanah and Pulungan, 2017).

The results of this study show that there were 28 man respondents experiencing SBS and there were 14 woman respondents experiencing SBS. It means that the man respondents experienced the symptoms more than the woman respondednts did. This is because, in this study, the number of male respondents was higher than that of female respondents. The results of this study is consistent with research conducted by Rahman, Naiem and Russeng which stated that the male gender experienced more SBS complaints as much as $43.9 \%$, compared to only $34.6 \%$ female respondents (Rahman, Naiem and Russeng, 2014).

However, the results of this study are inconsistent with Verayani statement saying that all female officers experienced complaints from SBS as women were more sensitive to various factors including the physical and psychosocial work environment. In addition, women were more likely to report psychosomatic complaints related to SBS they experienced (Verayani, 2018).

Moreover, Ridwan, Nopiyanti, and Susanto's research using multiple correlation tests shows that women were more at risk and experienced more SBS than men did. In theory, women reported symptoms more often than men did because women were more sensitive and responsive to symptoms (Ridwan, Nopiyanti and Susanto, 2018).

Moreover, the results of statistical tests about the period of work and the incidence of SBS show that there was no relationship between tenure and the incidence of SBS, having a $p$ value $\geq 0.05$. The results of this study is consistent with research by Annisa sstating that there was no significant relationship between work period and the incidence of SBS ( $p=1.000)$ (Asri, 2019).

However, the results of this study contradict to the statement by Rahmanet al. suggesting that more old respondents ( $\geq 5$ years) experienced SBS compared to new tenure ( $<5$ years) (Rahman, Naiem and Russeng, 2014). The longer a person works in a place, the more likely they are to be exposed to work environment factors, both physical and chemical factors, which can cause health problems or occupational diseases, including SBS. This in turn can cause a decrease in worker productivity.

A person's working period in a building can lead to chronic health problems; the longer the work period people have, the more health complaints they will experience. This is because the working period in the building affects the level of exposure of workers to pollutants in the room (Wahab, 2011).

The results of this study also show that in relation to the symptoms of SBS, most respondents' complaints were drowsiness, followed by flu symptoms. This can be due to the humidity level of the room that does not meet the standard as the room which is over humid and cold can cause drowsiness to the people staying there. This study is in line with Yazid, stating that the symptoms of SBS were malaise, fatigue, drowsiness, headache, runny noise/flu, inflammation,, swelling, and eye irritation (Yazdi, 2014).

\section{Physical Quality of Indoor Air}

Based on table 5, the temperature was abnormal of $\geq 28^{\circ} \mathrm{C}$. Extreme temperature conditions, both too high and too low, can make the body feel fatigue faster and experience symptoms such as eye irritation, throat irritation, and coughing, all of which are included as symptoms of SBS (Rahman, Naiem and Russeng, 2014). In addition, the temperature is closely related to body metabolism. Low temperature can reduce efficiency and cause complaints of a lack of muscle coordination. On the other hand, high temperature can reduce work performance and comfort in the building (Murniati, 2018). The results of statistical tests on the relationship between morning, afternoon and evening air temperature with the incidence of SBS show that the results of daytime and evening temperature had a significant relationship with the incidence of SBS, with $\mathrm{p}$ value $<0.05$, which means that temperaturehad an influence on the incidence of SBS. This shows that there was a significant effect between temperature and symptoms of SBS (Raharjo, Wiediartini and Dermawan, 2017).

Air temperature had a relationship with the incidence of SBS. The OR value obtained was 3.6363 (95\% CI $1.348-9.8099)$ meaning that respondents who worked at room temperatures that did not meet the standards $\left(\geq 25.5^{\circ} \mathrm{C}\right)$ dha a higher chance of 4.3864 times to experience SBS than respondents who worked in rooms that met the temperature terms (Ridwan, Nopiyanti and Susanto, 2018).

The heat can degrade indoor air quality and affect human comfort when living or working in the space. The air temperature is instrumental in the comfort of work for the human body to produce 
heat which is used for basal metabolism and muscle metabolism. When the air temperature in work space is too cold, it can cause distractions for the employees and can cause concentration disorders where the comfort at work cannot be obtained.

Meanwhile, the high temperature of the air can accelerate the change in gas levels or pollutants in the air. The higher the air temperature, the drier and lighter the particles will be so that these particles become more reactive and last longer in the air. In fact, changes in air temperature in the room can be influenced by natural and artificial (mechanical) ventilation factors and structural materials of the building. The type of plasterboard ceiling used by industry affects the quality of the temperature in the room because the heat from the outside is absorbed through the ceiling. The density of the occupancy with the number of workers in the room also contributes to the room temperature (Oktaviani and Prasasti, 2015).

At high air temperatures, air humidity can increase and cause water vapor levels in the air to react with air pollutants into other substances (Mukono, 2014). Air humidity can affect the concentration of dust particles in the air. The higher the humidity, the higher the possibility of air pollutants reacting with water, so the density of the pollutants will increase (Oktaviani and Prasasti, 2015).

Temperatures that are too high can also cause a person to lose fluids more rapidly, and in the extreme level it can lead to heat stroke. Even at low temperatures a person needs to work hard to maintain the temperature to remain at normal conditions. In other words, in extreme conditions of the temperature, both too high and too low, the body needs to adjust faster to avoid experiencing the symptoms such as eye irritation, throat irritation, and cough, including SBS symptoms (Rahman, Naiem and Russeng, 2014).

The air temperature in the room and the working environment is one of the important factors for the occurrence of SBS. David Wyson's research entitled Effect of The Indoor Environment on Health shows that the human body. In this case, the balance system for body temperature is highly dependent on the surrounding air temperature conditions. Air temperature that does not meet the requirement could decrease the speed of working, concentration and sensitivity by up to $20 \%$ (Sumarni, 2012).

In addition, in this study, the humidity was in abnormal number. Too high humidity is a risk factor for SBS because high humidity can increase the growth of microorganisms and release formaldehyde out of the building materials. Research conducted by Wulandari (2013) showed that humidity $\geq$ $60 \%$ would cause the presence of Streptococcus bacteria. She noted that symptoms that appeared in relative humidity above $60 \%$ were eye irritation, eye tiredness and sneezing. On the other hand, relative humidity below $30 \%$ and above $60 \%$ can increase the growth of bacteria and viruses proliferating at a relative humidity below $50 \%$ and above $70 \%$ (Wulandari, 2013).

The appearances of bacteria, viruses and other organic matter can cause health manifestations both infection and irritation. Thus, the appearances of SBS symptoms in the form of sneezing and eye irritation could be one of the immune responses to foreign materials (it could be organic materials in the form of bacteria, fungi or viruses) that enter the respiratory tract, although etiologically it is difficult to explain (Ardian and Sudarmaji, 2014).

Besides, the result shows that that the light intensity was at an abnormal. The measurement on the level of light intensity in the AHN IPB in the building workspace had a value that was not in accordance with the quality standard at all measurement locations (Lazuardi, 2016). The measured value varied greatly of $7.83-182.13$ lux. This value was far below the quality standard that must be achieved of 350 lux. Light intensity can be influenced by several factors, namely the poor quality of the lights used, the lack of lights used, the uneven location of the lights, the number of windows that do not match the area of the room, so there is less natural lighting in a room (Ardian and Sudarmaji, 2014). The lighting in the workplace must be adequate since low-intensity work will lead to fatigue, eye strain and complaints of soreness around the eyes (Suma'mur, 2014).

\section{Indoor Air Chemical Quality}

Based on table 6 , the results of this study are not in line with the research conducted by Adrian (2014) which stated that there was no significant effect of dust concentration on the appearance of symptoms and cases of SBS. SBS cases and almost all of SBS symptoms were more frequent in respondents who lived in rooms with dust concentrations less than $0.014 \mathrm{mg} / \mathrm{m} 3$. The dust produced in the office area affected the emergence of psychological changes and symptoms of sensory disorder in the eyes and nose (Ardian and Sudarmaji, 2014).

Almost all symptoms of SBS were suffered by respondents who lived in rooms with $\mathrm{CO}_{2}$ 
concentrations below the average. Meanwhile, only stuffy nose was common to respondents who lived in rooms above average $\mathrm{CO}_{2}$ concentrations. The results of this study also show that the $\mathrm{CO}_{2}$ concentration did not significantly influence the appearance of SBS symptoms. There was another theory explaining that only a $\mathrm{CO}_{2}$ concentration at $75 \%$ (7500 ppm) could cause symptoms (Ardian and Sudarmaji, 2014).

The standard for PM2.5 dust levels in the workspace is regulated by WHO, suggesting that the daily concentration of PM2.5 dust allowed for 24 hours is $25 \mu \mathrm{g} / \mathrm{m}^{3}$ and $10 \mu \mathrm{g} / \mathrm{m}^{3}$ for an average per year. The level of dust particles that do not meet the threshold value will certainly pose a risk of health complaints (Oktaviani and Prasasti, 2015).

Excessive dust exposure can have an impact on human pathological damage. However, this damage depends on the nature, intensity, duration of exposure, and individual susceptibility. According to EPA, M2.5 is dust particles measuring $\leq 2.5$ micrometers or less than $1 / 30$ of the diameter of a human hair. The main sources of PM2.5 are burning, cigarette smoke, cooking with firewood and agricultural activities (Aulia and Azizah, 2015).

Particles like dust and gas in the work space can lead to reactions such as cough which can cause irritation of mucous in the respiratory tract. Coughing occurs in the form of a sudden expulsion of air and mucus and is accompanied by a sound. Coughing is the earliest symptom that results from constant exposure to air pollutants. Reflex cough pushes secretions upward so that objects that enter the respiratory tract can be swallowed or expelled (Oktaviani and Prasasti, 2015). The dust particles under certain conditions are a hazard that can lead to a reduction in work comfort, visual disturbances, respiratory problems and even can cause general poisoning (Oktaviani and Prasasti, 2015).

\section{Microbiological Quality of Indoor Air}

Based on table 7, the result of this research is consistent with Verayani's research, stating that the results of measurement of germ numbers in the air in the crossmatch laboratory and blood service rooms met the standards of the Minister of Health RI No.1204 / Menkes / SK / X / 2004 Hospital Environmental Health Requirements, even though the air germ count in the crossmatch laboratory was smaller and lower than the standard limit for the number of air germs in the laboratory. This condition has the potential to cause health problems such as complaints related to sick building syndrome such as eye and nose irritation, skin, sneezing, and hypersensitivity reactions (Verayani, 2018). Based on research conducted by Verayani, it is shown that humidity is the largest physical environmental factor that greatly affects the number of air germs in the room (Verayani, 2018).

Moreover, the building has high humidity, so it is a good place for microbiological growth. The large number of microbiological colonies in the air depends on indoor activities and the amount of dust and other impurities. A dirty room will contain air that contains more microbiology than a clean room will. In addition, microbiology requires an adequate environment for optimal growth. In a room that does not use an air conditioner, the influence of air from outside the building plays a very important role, such as temperature and humidity. In the rainy season, the air temperature is relatively low and humidity is very high, so it is an excellent medium for microbiological growth (Rissanty, 2006). The number of air germs is also influenced by unhealthy behavior and the frequency of room cleaning (Verayani, 2018).

\section{CONCLUSION}

Based on the results of measurement, the factors that influence the occurrence of SBS were air temperature and dust concentration in the room. So, it can be concluded that there was a significant relationship between air temperature and dust levels on the incidence of Sick Building Syndrome (SBS).

\section{ACKNOWLEDGEMENTS}

We would like to say Alhamdulillah to Allah Subhanahu Wa Ta'ala. Also, our thanks are delivered to overall administration and policy staff of Polytechnic of Health, Ministry of Health, Mamuju Regency. Besides, the authors thank all participants in this research.

\section{REFERENCES}

Ardian, A. E. and Sudarmaji (2014) 'Faktor yang Mempengaruhi Sick Building Syndrome di Ruangan Kantor', Jurnal Kesehatan dan Lingkungan, 7(2), pp. 107-117.

Asri, A.N,. (2019) 'Hubungan Lingkungan Kerja Dengan Gejala Sick Building Syndrome 
Pada Pegawai BPJS Kesehatan Depok', JPH REECODE, 3(1), pp. 44-55.

Aulia, Z. and Azizah, R. (2015) 'Karakteristik, Perilaku, Fungsi Paru Pekerja Dan Kadar Pm 2,5 Di Industri Rumah Tangga Cecek Kabupaten Sidoarjo Characteristic, Behaviour, Lung Function Of Workers And PM 2,5 Concentration In Cecek Home Industry Sidoarjo Regency', Jurnal Kesehatan Lingkungan, 8(1), pp. 128-136.

Ikmala, R., Ma'rufi, I. and Munawir, A. (2018) 'Individual Characteristic, Antibody, Work Environtment and Sick Building Syndrome (SBS)', Health Nations, 2(5), pp. 546-549.

Lazuardi, W. (2016) Pemantauan Kondisi Kualitas Air Dan Udara Dalam Ruangan Di Gedung Andi Hakim Nasoetion Institut Pertanian Bogor. Undergraduate Thesis. Bogor: Fakultas Teknologi Pertanian, Institut Pertanian Bogor.

Mukono (2014) Pencemaran Udara Dalam Ruangan. Surabaya: Airlangga University Press.

Murniati, N. (2018) 'Hubungan Suhu dan Kelembaban dengan Keluhan Sick Building Syndrome pada Petugas Administrasi Rumah Sakit Swasta X', Jurnal Ilmu Kesehatan Masyarakat, 7(3), pp. 148-154.

Oktaviani, D. A. and Prasasti, C. I. (2015) 'Kualitas fisik dan kimia udara, karakteristik pekerja, serta keluhan pernapasan pada pekerja percetakan di surabaya', Jurnal Kesehatan Lingkungan, 8(2), pp. 195-205.

Raharjo, H. D., Wiediartini and Dermawan, D. (2017) Analisis Pengaruh Karakteristik Individu dan Faktor Fisik Terhadap Gejala Sick Building Syndrome Pada Pegawai di Gedung Utama Perusahaan Fabrikasi Kapal. Diploma Thesis. Politeknik Perkapalan Negeri Surabaya.

Rahman, N. H., Naiem, F. and Russeng, S. (2014) 'Studi tentang Keluhan Sick Building Syndrome (SBS) pada Pegawai di Gedung Rektorat Universitas Hasanuddin Makassar', Scientific Article. Makassar: Faculty of Public Health, Universitas Hasanuddin.
Ridwan, A. M., Nopiyanti, E. and Susanto, A. J. (2018) 'Analisis Gejala Sick Building Syndrome Pada Pegawai Di Unit OK Rumah Sakit Marinir Cilandak Jakarta Selatan', Jurnal Kesehatan Masyarakat, 2(1), pp. 116-133.

Rissanty, D. S. (2006) Hubungan Antara Kualitas Fisik Dan Mikrobiologi Udara Dengan Keluhan Sick Building Syndrome Pada Unit Cutting Dan Sewing PT. Sai Apparel Industries Semarang Tahun 2016. Undergraduate Thesis. Semarang: Faculty of Health, Universitas Dian Nuswantoro.

Saffanah, S. and Pulungan, R. M. (2017) 'Faktor Risiko Gejala Sick Building Syndrome Pada Pegawai BPPSDM Kesehatan RI', Jurnal Ilmu Kesehatan, 3(1), pp. 8-15.

Suma'mur (2014) Higiene Perusahaan dan Kesehatan Kerja (HIPERKES). Jakarta: Sagung Seto.

Sumarni (2012) Gambaran Kejadian Sick Building Syndrome (SBS) Pada Karyawan Fajar Group di Gedung PT. Fajar Graha Pena Makassar. Undergraduate Thesis. Makassar: Faculty of Health Sciences, UIN Alauddin Makassar.

Verayani, E. (2018) 'Identifikasi Legionella, Kualitas Udara Ruang dan Keluhan Sick Building Syndrome Pada Petugas Instalasi Transfusi Darah RSUD Dr. Soetomo', Jurnal Kesehatan Lingkungan, 10(3), pp. 299-305.

Wahab, S. A. A. (2011) Sick Building Syndrome in Public Buildings and Workplaces. Newyork: Springer.

Wulandari, E. (2013) 'Faktor Yang Berhubungan Dengan Keberadaan Streptococcus Di Udara Pada Rumah Susun Kelurahan Bandarharjo Kota Semarang Tahun 2013', Unnes Journal of Public Health, 2(4), pp. 1-10.

Yazdi, H. K. and Y. fathalizadeh (2014) 'Relationship between Sick Building Syndrome with Headache and Drowsiness Hamid', International journal of Advanced Biological and Biomedical Research, 2(2), pp. 510-516. 